\title{
DE-OXIDATION OF PK942 STEEL WITH Ti AND Zr DEZOKSIDACIJA JEKLA PK942 S Ti IN Zr
}

\author{
Mitja Koležnik ${ }^{1}$, Jaka Burja ${ }^{2}$, Barbara Šetina Batič ${ }^{2}$, Aleš Nagode ${ }^{3}$, \\ Jožef Medved ${ }^{3}$ \\ ${ }^{1}$ Metal Ravne d.o.o., Koroška cesta 14, 2390 Ravne na Koroškem, Slovenia \\ 2Institute of Metals and technology, IMT, Lepi pot 11, 1000 Ljubljana, Slovenia \\ ${ }^{3}$ Faculty of Natural Sciences and Engineering Ljubljana, Aškerčeva cesta 12, 1000 Ljubljana, Slovenia \\ mitja.koleznik@metalravne.com
}

Prejem rokopisa - received: 2017-06-22; sprejem za objavo - accepted for publication: 2017-09-12

\author{
doi:10.17222/mit.2017.082
}

The effects of titanium and zirconium additions on the non-metallic inclusions and microstructure of PK942 (X11CrNiMo12) steel were investigated. Laboratory steel charges with additions of $\mathrm{Ti}, \mathrm{Zr}$ and a combination of both elements were melted. The inclusions' size, quantity, distribution and composition were analysed using optical and scanning electron microscopy (SEM). Other than the difference in $\delta$-ferrite quantity, there are no significant differences in the microstructure. The Ti and $\mathrm{Zr}$ additions had a significant effect on the non-metallic inclusions, and while the addition of Ti did have an effect on the composition of inclusions, the addition of $\mathrm{Zr}$ also had a great effect on the size distribution and the number of non-metallic inclusions. The result of the $\mathrm{Zr}$ addition was a large reduction in the total non-metallic inclusion surface area. The additions of both titanium and zirconium had similar effects to the addition of Zr. Thermodynamic reactions were considered to explain the modification of the non-metallic inclusions.

Keywords: non-metallic inclusions, clean steel, de-oxidation with Ti, de-oxidation with $\mathrm{Zr}$, creep resistant steel

S pomočjo optične ter elektronske mikroskopije se je preiskal vpliv dezoksidacije jekla PK942 (X11CrNiMo12) s cirkonijem, titanom ter kombinacijo obeh. Poudarek raziskave je bil na spremembi velikosti, razporeditve ter sestave nekovinskih vključkov v jeklu PK942. Razen v majhni razliki deleža $\delta$-ferita, ni bilo bistvenega vpliva na osnovno mikrostrukturo jekla. Večji vpliv pa se je pokazal na velikost, število ter kemično sestavo nekovinskih vključkov. Analiza nekovinskih vključkov je pokazala, da Ti vpliva predvsem na kemično sestavo, med tem ko ima Zr zelo velik vpliv tudi na velikostno porazdelitev ter število nekovinskih vključkov, rezultat česar je manjši skupni površinski delež nekovinskih vključkov. Dodatek kombinacije Zr in Ti ima podoben vpliv kot dodatek Zr, vendar v manjšem obsegu. Pri razlagi modifikacije vključkov so se upoštevale osnovne termodinamične reakcije oksidacije.

Ključne besede: nekovinski vključki, čistost jekla, dezoksidacija s Ti, dezoksidacija z Zr, jekla za lezenje

\section{INTRODUCTION}

The efficiency of steam turbines can be improved by increasing the maximum operating pressure and temperature, which are limited by the properties of the available materials. ${ }^{1}$ The most widely used creep-resistant steels in a power plant are 9-12\% Cr martensitic steels, where the size, number and distribution of the precipitates affect the creep resistance. ${ }^{2-6}$ They offer the best combination of high creep strength, high resistance against thermal fatigue, high steam oxidation resistance and good manufacturability at relatively low costs. ${ }^{7}$ The steel grade PK942 (X11CrNiMo12) is a martensitic creep-resistant steel that is generally used for turbine blades and fittings.

These steels must fulfil very high quality standards in terms of the mechanical properties and microstructure. One of very important factors is the cleanliness of steel, which depends on the number, size, and distribution of non-metallic inclusions. The content of non-metallic inclusions depends on the control of melting, refining and casting of steel. ${ }^{8}$ The use of de-oxidation agents is very important as they will greatly influence the forma- tion of inclusions, both during refining and casting. De-oxidization is usually carried out through Al additions, but aluminates are hard and brittle, and are unfavourable. Alternatively, de-oxidation can also be performed with elements that have a very high chemical affinity for oxygen, like titanium and zirconium, this changes the size, number and distribution of nonmetallic inclusions. ${ }^{9}$ Zirconium and titanium additions are known to modify sulphide inclusions, cause grain refinement, reduce the grain growth during high-temperature annealing and in the heat-affected zone during welding, they also promote the precipitation of small nitride, carbide and carbonitride particles. ${ }^{10-15}$ The use of both titanium and zirconium are known to reduce the size and improve the distribution of oxide inclusions in steel. ${ }^{16}$

The present investigation was undertaken with the objective of determining the effect of small additions of $\mathrm{Zr}$, Ti and the combination of both elements, on the size, distribution and composition of inclusions in PK942 steel grade. 
M. KOLEŽNIK et al.: DE-OXIDATION OF PK942 STEEL WITH Ti AND Zr

Table 1: Chemical compositions of the experimental charges / wt.\%

\begin{tabular}{|c|c|c|c|c|c|c|c|c|c|c|c|c|c|}
\hline sample & $\mathrm{C}$ & $\mathrm{Si}$ & $\mathrm{Mn}$ & $\mathrm{Cr}$ & $\mathrm{Ni}$ & $\mathrm{Mo}$ & $\mathrm{V}$ & $\mathrm{Al}$ & $\mathrm{Ti}$ & $\mathrm{Zr}$ & $\mathrm{O}$ & $\mathrm{N}$ & $\mathrm{Fe}$ \\
\hline PK942 & 0.11 & 0.37 & 0.80 & 12.8 & 2.68 & 1.61 & 0.41 & 0.004 & $<0.001$ & $<0.001$ & 0.0126 & 0.038 & $\mathrm{Bal}$. \\
\hline PK942Ti & 0.12 & 0.39 & 0.80 & 12.6 & 2.67 & 1.60 & 0.40 & 0.006 & 0.018 & $<0.001$ & 0.0119 & 0.045 & $\mathrm{Bal}$. \\
\hline PK942Zr & 0.10 & 0.26 & 0.58 & 12.4 & 2.69 & 1.62 & 0.37 & 0.005 & $<0.001$ & 0.013 & 0.0148 & 0.038 & Bal. \\
\hline PK942TiZr & 0.11 & 0.45 & 0.90 & 12.7 & 2.65 & 1.60 & 0.38 & 0.006 & 0.016 & 0.010 & 0.0105 & 0.038 & Bal. \\
\hline
\end{tabular}

\section{EXPERIMENTAL}

\subsection{Melting and casting}

Experimental charges of PK942 (X11CrNiMo12, SINOX 4938) steel were remelted in a vacuuminduction-melting furnace under an inert $\mathrm{Ar}$ atmosphere. The four charges consisted of $8 \mathrm{~kg}$ of X11CrNiMo12 and minor additions of ferrosilicon $(20 \mathrm{~g})$, ferrovanadium $(4 \mathrm{~g})$ and ferromanganese $(50 \mathrm{~g})$ were added to compensate for the oxidation losses. The first charge (PK942) was remelted without any additional alloys, the second charge (PK942Ti) was de-oxidised with the addition of ferrotitanium (70 \% Ti), the third charge (PK942Zr) was de-oxidised by adding zirconium $(99.8 \% \mathrm{Zr}$ ), and the fourth charge (PK942TiZr) was de-oxidised by adding both ferrotitanium and $\mathrm{Zr}$. The melt was cast into $88 \mathrm{~mm}$ $\times 88 \mathrm{~mm}$ moulds. The cast ingots were air cooled to room temperature.

\subsection{Forging and heat treatment}

Then the ingots were annealed at $720{ }^{\circ} \mathrm{C}$ to prevent stress cracking. The annealed ingots were then homogenized at $1180{ }^{\circ} \mathrm{C}$ for 6 hours. When the homogenization was complete the $88 \times 88 \mathrm{~mm}$ ingots were hot forged into 30 -mm diameter bars with a pneumatic forging hammer. After hot forging the samples were annealed at $720{ }^{\circ} \mathrm{C}$ for $1.5 \mathrm{~h}$.

\subsection{Sampling}

The samples were then taken from the forged bars, in the longitudinal direction, as described in Figure 1.

\subsection{Chemical analysis}

The chemical analysis of the steel samples was made by time-of-flight mass spectrometers (TOFMS) LECO CS600 ( $\mathrm{C}$ and S) and LECO TC436 ( $\mathrm{N}$ and $\mathrm{O}$ ), by Coupled Plasma-Optical Emission Spectrometers (ICP-OES) Varian 730-ES ( $\mathrm{Ti}$ and $\mathrm{Zr}$ ), and by Optical



Figure 1: Site of the sample extraction
Emission Spectroscopy (OES) ARL 3460 (Si, Mn, Cr, $\mathrm{Ni}, \mathrm{Mo}, \mathrm{V}$ and $\mathrm{Al})$.

\subsection{Metallography}

The metallographic analysis and the determination of the prior austenite grain size according to ASTM E112 17 were made with an optical microscope (Olympus DP70). The samples for optical microscopy were etched with Vilella's reagent, while the samples for electron microscopy were only polished.

The electron microscopy and EDS analysis were made in a SEM (Jeol-JSM6500F). The non-metallic inclusion analysis was made with an INCA FEATURE in a SEM Jeol-JSM6510. The total analysis area for each sample was $9 \times 10^{6} \mu \mathrm{m}^{2}$.

\subsection{Thermodynamic}

The calculation of the Gibbs free energy and its dependence on the temperature were made with HTCS 8 software.

\section{RESULTS AND DISCUSSION}

The chemical analyses of the four different charges PK942, PK942Ti, PK942Zr and PK942TiZr are given in Table 1. The most important variations of the experimental charges in comparison to PK942 are $0.018 \%$ of mass fractions of $\mathrm{Ti}$ in PK942Ti, 0.013\% of mass fractions of $\mathrm{Zr}$ in $\mathrm{PK} 942 \mathrm{Zr}$, and $0.016 \%$ of mass fractions of

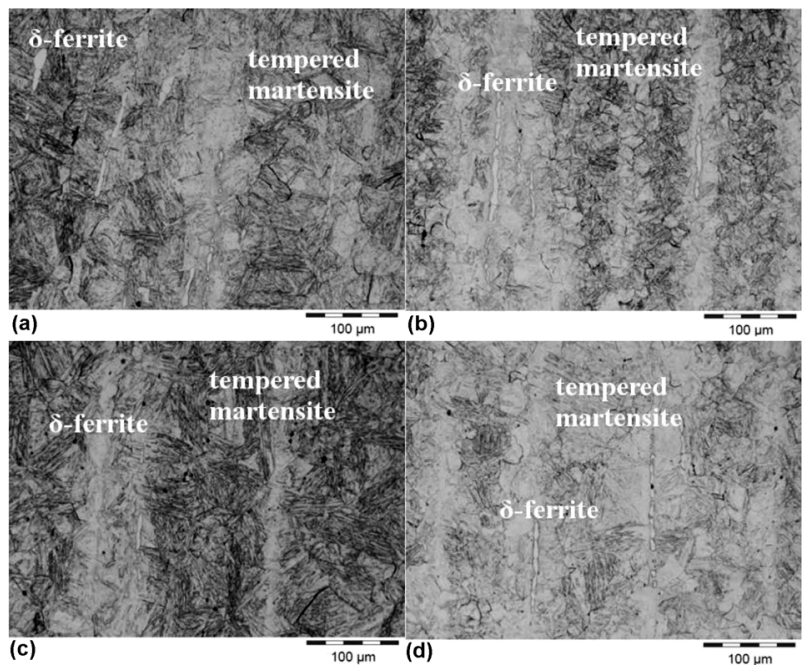

Figure 2: Microstructure of quenched and tempered sample a) PK942, b) PK942Ti, c) PK942 Zr, d) PK942TiZr 
M. KOLEŽNIK et al.: DE-OXIDATION OF PK942 STEEL WITH Ti AND Zr

Ti and $0.01 \%$ of mass fractions of $\mathrm{Zr}$ in PK942TiZr, as can be seen in Table $\mathbf{1}$.

The chemical analyses showed that the oxygen content in the charges varies from $0.0105 \%$ to $0.0148 \%$ of mass fractions, while the nitrogen content is $0.038 \%$ of mass fractions, except for PK942Ti, where it is $0.045 \%$ of mass fractions. These values of the measurements can be considered to be roughly the same for practical purposes. Although the higher nitrogen content could be attributed to the formation of titanium nitrides in the liquid melt.

The microstructures are shown in Figure 2 a to $\mathbf{2 d}$. All four types of steel contain martensite with small $\delta$-ferrite islands in the segregation areas. The prior austenite grain size of all the samples was 5 according to ASTM E1 12. ${ }^{17}$ The occurrence of $\delta$-ferrite islands is less frequent in the PK942Zr sample, which may be explained by the fact that $\mathrm{ZrO}_{2}$ is a heterogeneous nucleation site during the solidification of austenite, therefore inhibiting $\delta$-ferrite nucleation. ${ }^{18}$ This can be beneficial as $\delta$-ferrite can be harmful to the final properties and the hot working is reduced by annealing. ${ }^{19}$ Other than the difference in $\delta$-ferrite, there are no significant differences in the microstructure.

\subsection{INCA-feature}

The automatic non-metallic inclusion analysis made by the INCA Feature revealed significant differences in the non-metallic inclusion content and chemistry between the samples. The graph in Figure $\mathbf{3}$ shows the total area of all the inclusions and the number of inclusions found in the INCA-feature analysis. The total analysis area for each sample was $9 \times 10^{6} \mu \mathrm{m}^{2}$.

The results of the Inca feature analysis are given in Figure 3. The non-metallic inclusion area drastically decreases with the $\mathrm{Zr}$ additions, but the number of inclusions, however, sharply increases. This means that $\mathrm{Zr}$ additions cause the formation of numerous small nonmetallic inclusions. The explanation for the smaller $\mathrm{ZrO}_{2}$ non-metallic inclusions, especially in comparison to the

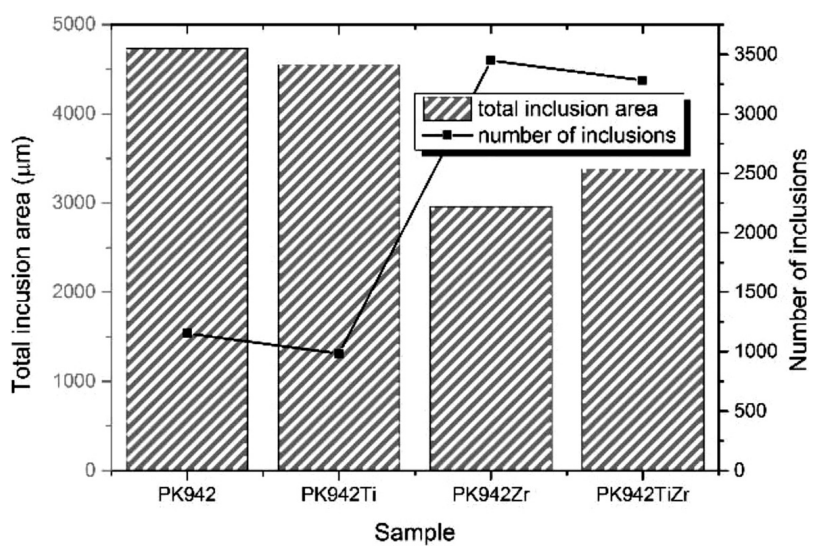

Figure 3: Total inclusion area and number of inclusions for each sample

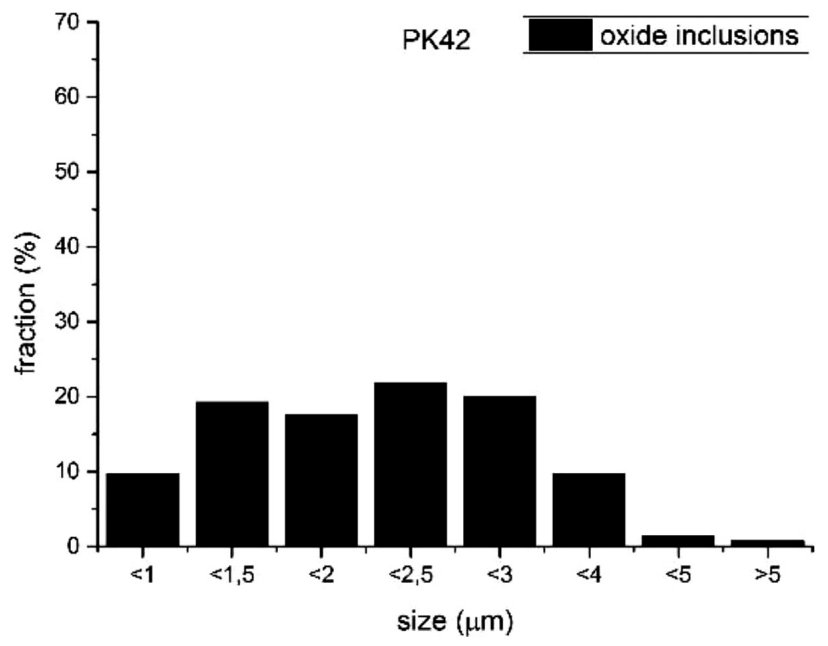

Figure 4: Size distribution of non-metallic inclusions for sample PK942

alumina inclusions, is the lower interfacial energy and better wettability. During solidification the $\mathrm{ZrO}_{2}$ particles are engulfed by the solidification front, while the alumina particles are pushed from the solidification front. ${ }^{20}$

The Ti additions have no significant effect on the total surface and the number of inclusions. The combined addition of $\mathrm{Ti}$ and $\mathrm{Zr}$ results in a decrease in the total inclusion area and an increase in the number of inclusions.

The distribution of inclusions in each sample according to their diameter is shown in Figures 4-7. It can be observed that while the PK942 and PK942Ti samples (Figures 4-5) have a relatively uniform distribution of inclusions of different sizes, the majority of the inclusions in the PK942Zr and PK942TiZr samples (Figures 6-7) are smaller than $1 \mu \mathrm{m}$. This is in good agreement with the research of A. V. Karasev and H. Suito, where the majority of the $\mathrm{Zr}$ de-oxidation product inclusions were less than $1 \mu \mathrm{m}$ in diameter.

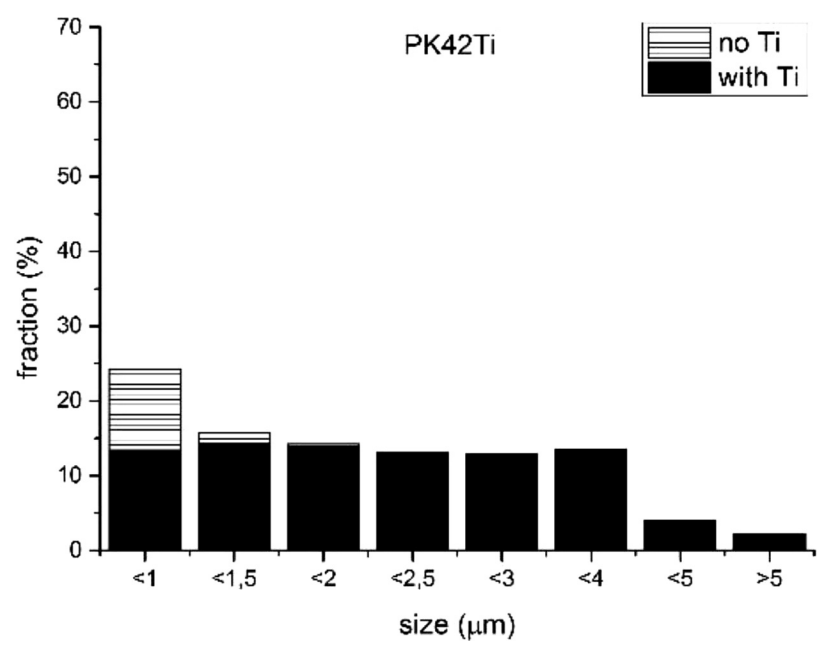

Figure 5: Size distribution of non-metallic inclusions for sample PK942Ti 
M. KOLEŽNIK et al.: DE-OXIDATION OF PK942 STEEL WITH Ti AND Zr

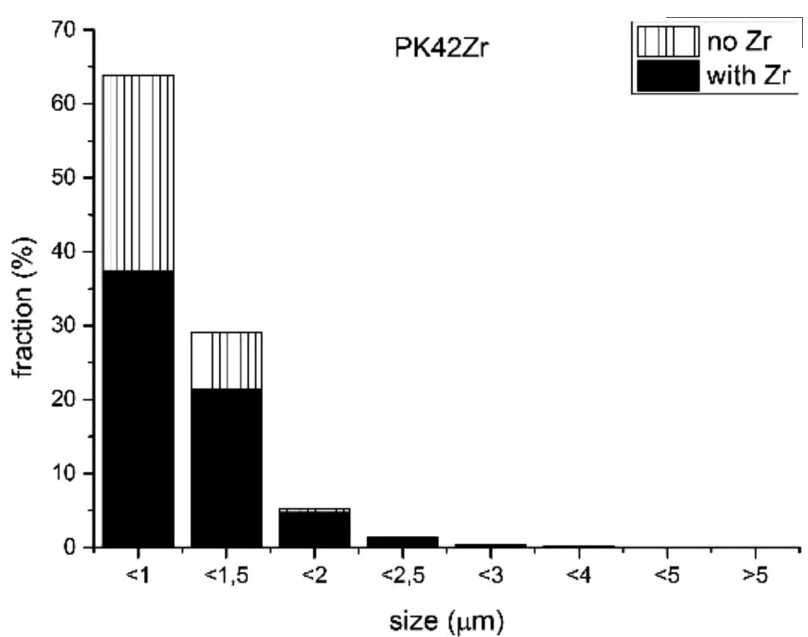

Figure 6: Size distribution of non-metallic inclusions for sample PK942Zr

The non-metallic inclusions in PK942 are relatively equally distributed among the sizes from 1 to $4 \mu \mathrm{m}$. The inclusions are relatively small but compared to Figure 6 (PK942Zr and PK942TiZr) they are large. The PK942 sample has the highest surface area of non-metallic inclusions, compared to the other samples in Figure 3.

For PK942Ti the inclusion size and distribution are comparable to PK942, but most of the inclusions were modified by the $\mathrm{Ti}$, especially the larger inclusions. Only a few smaller inclusions contain no titanium. The analysis of the non-metallic inclusions is very similar to PK942, both in the distribution of the non-metallic inclusion size as well as in the non-metallic inclusion surface area.

The addition of $\mathrm{Zr}$ drastically changed the inclusion size distribution, as the majority of the inclusions (over $60 \%$ ) are smaller than $1 \mu \mathrm{m}$ in diameter. The majority of the inclusions also contain $\mathrm{Zr}$. The highest percentage of inclusions without $\mathrm{Zr}$ is smaller than $1 \mu \mathrm{m}$ in diameter. The share of non-modified inclusions is larger than in the

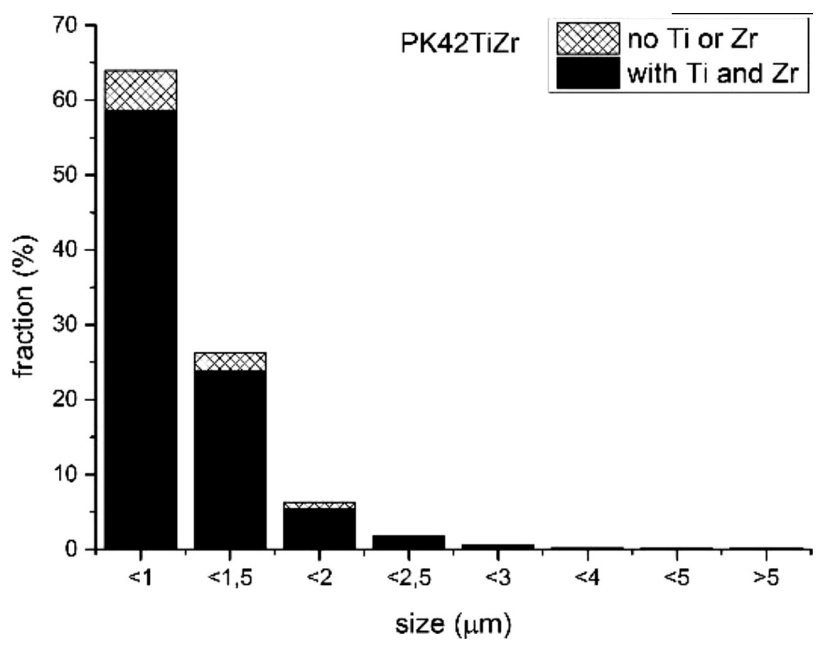

Figure 7: Size distribution of non-metallic inclusions for the sample PK942TiZr
PK942Ti sample. The overall inclusion surface area is the smallest, as can be seen in Figure 3, but the number of inclusions is the highest.

The combination of $\mathrm{Ti}$ and $\mathrm{Zr}$ additions has a high percentage of modified inclusions, similar to PK942Ti, and the majority of the inclusions are smaller than $1 \mu \mathrm{m}$ in diameter, similar to PK942Zr. The overall surface area of the non-metallic inclusions is higher than in PK942Zr, but still much lower than in PK942 and PK942Ti (Figure 3).

\subsection{Thermodynamics}

When adding elements like $\mathrm{Ti}$ and $\mathrm{Zr}$ the basic thermodynamic reactions must be considered. For steelmaking the reactions with oxygen must be considered when estimating the alloy addition yield. Figure 8 shows a diagram with the Gibbs free energy and its dependence on the temperature in degrees Celsius. Titanium has a high affinity for oxygen, higher than silicon, while zirconium has higher affinity for oxygen, even higher than aluminium, as can be seen in Figure 8. The high affinity for oxygen is one of the reasons so much of both titanium and zirconium are present in the non-metallic inclusions. The exact thermodynamic values were taken from the HTCS 8 software, and are given in Table 2 at $1600{ }^{\circ} \mathrm{C}$.

Table 2: Reactions and associated values of $\Delta \mathrm{H}, \Delta \mathrm{S}$ and $\Delta \mathrm{G}$ at $1600{ }^{\circ} \mathrm{C}$

\begin{tabular}{|l|c|c|c|}
\hline \multicolumn{1}{|c|}{ Reaction } & $\Delta \mathrm{H}(\mathrm{kJ})$ & $\Delta \mathrm{S}(\mathrm{J} / \mathrm{K})$ & $\Delta \mathrm{G}(\mathrm{kJ})$ \\
\hline $4 / 3 \mathrm{Al}+\mathrm{O}_{2}(\mathrm{~g})=2 / 3 \mathrm{Al}_{2} \mathrm{O}_{3}$ & -1120.9 & -215.7 & -716.8 \\
\hline $2 \mathrm{Ca}+\mathrm{O}_{2}(\mathrm{~g})=2 \mathrm{CaO}$ & -1288.9 & -226.2 & -910.5 \\
\hline $4 / 3 \mathrm{Cr}+\mathrm{O}_{2}(\mathrm{~g})=2 / 3 \mathrm{Cr}_{2} \mathrm{O}_{3}$ & -751.9 & -166.8 & -439.5 \\
\hline $2 \mathrm{Mn}+\mathrm{O}_{2}(\mathrm{~g})=2 \mathrm{MnO}$ & -812.1 & -175.7 & -482.9 \\
\hline $\mathrm{Si}+\mathrm{O}_{2}(\mathrm{~g})=\mathrm{SiO}_{2}$ & -946.3 & -197.9 & -575.7 \\
\hline $\mathrm{Ti}+\mathrm{O}_{2}(\mathrm{~g})=\mathrm{TiO}_{2}$ & -937.5 & -175.8 & -608.1 \\
\hline $\mathrm{Zr}+\mathrm{O}_{2}(\mathrm{~g})=\mathrm{ZrO}_{2}$ & -1080.6 & -175.8 & -751.3 \\
\hline
\end{tabular}

The reactions of the different alloying elements were calculated to represent the reduction of 1 mole of $\mathrm{O}_{2}(\mathrm{~g})$.

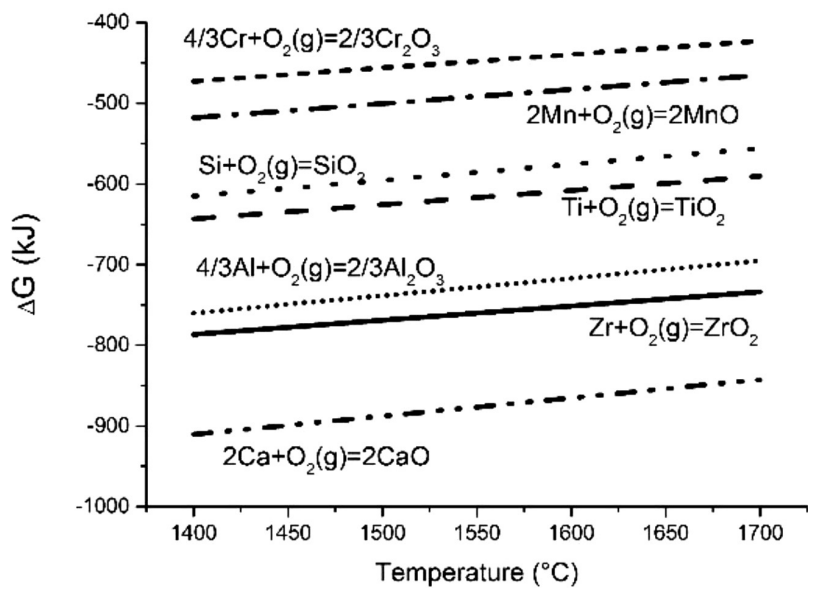

Figure 8: Gibbs free energy for the formation of different oxides 
M. KOLEŽNIK et al.: DE-OXIDATION OF PK942 STEEL WITH Ti AND Zr

Table 3: Chemical composition of the typical oxide inclusion in Figure 9

\begin{tabular}{|c|c|c|c|c|c|c|c|c|c|c|}
\hline \multirow{2}{*}{ sample } & \multicolumn{9}{|c|}{ wt. \%* } \\
\cline { 2 - 13 } & $\mathrm{O}$ & $\mathrm{S}$ & $\mathrm{Zr}$ & $\mathrm{Ti}$ & $\mathrm{Cr}$ & $\mathrm{Mn}$ & $\mathrm{V}$ & $\mathrm{Si}$ & $\mathrm{Al}$ & $\mathrm{Fe}$ \\
\hline PK942-Spect1 & 40.1 & $/$ & $/$ & $/$ & 4.3 & 25.4 & $/$ & 20.4 & $/$ & 9.8 \\
\hline PK942Ti-Spect1 & 14.52 & $/$ & $/$ & 9.57 & 10.32 & 1.22 & 1.65 & 5.13 & 0.97 & 56.62 \\
\hline PK942Ti-Spect2 & 34.04 & $/$ & $/$ & 41.18 & 6.63 & 5.03 & 6.28 & $/$ & 0.75 & 6.09 \\
\hline PK942Ti-Spect3 & $/$ & $/$ & $/$ & 12.34 & 12.90 & 1.19 & 2.64 & $/$ & $/$ & 70.93 \\
\hline PK942Ti-Spect4 & 32.00 & $/$ & $/$ & 32.54 & 7.50 & 4.53 & 4.66 & 1.29 & 0.93 & 16.55 \\
\hline PK942Zr-Spect1 & 27.57 & $/$ & 67.57 & $/$ & 0.78 & $/$ & $/$ & 0.68 & $/$ & 3.39 \\
\hline PK942Zr-Spect2 & 28.65 & $/$ & 26.92 & $/$ & 15.62 & 9.59 & 2.43 & 1.15 & 0.66 & 14.97 \\
\hline PK942Zr-Spect3 & 31.92 & $/$ & 35.25 & $/$ & 7.68 & 3.95 & 1.18 & 4.78 & $/$ & 15.24 \\
\hline PK942TiZr-Spect1 & 24.9 & $/$ & 50.7 & 7.0 & 4.2 & 1.6 & 0.8 & $/$ & 0.5 & 10.3 \\
\hline PK942TiZr-Spect2 & 5.9 & 13.5 & 12.6 & 5.1 & 7.3 & 28.4 & 1.5 & $/$ & 0.4 & 25.3 \\
\hline PK942TiZr-Spect3 & $/$ & $/$ & $/$ & $/$ & 14.0 & 1.2 & 0.6 & 0.6 & $/$ & 83.6 \\
\hline
\end{tabular}

*The carbon content was omitted from the results as it cannot be properly measured by the SEM EDS method and would only potentially confuse the reader into thinking there were carbides in the inclusions.

According to Figure 8, zirconium oxide is more stable than aluminium oxide, which means that zirconium will be a better de-oxidiser than aluminium. This explains why a large amount of the non-metallic inclusions contain zirconium. Zirconium reduced most of the inclusions in the melt and formed new, smaller inclusions and completely changed the size distribution and the amount of the non-metallic inclusions (Figure 6). Titanium, however, forms less-stable oxides than aluminium, but since there were no aluminium additions to the melt, it also acted as a strong de-oxidiser. Titanium only partially reduced the pre-existing inclusions; therefore, it did not have a profound effect on the number and size distribution of the non-metallic inclusions, but titanium was present in the majority of the inclusions (Figure 5).

The combined addition of both titanium and zirconium had a similar effect on the size and distribution of the non-metallic inclusions to that of the zirconium
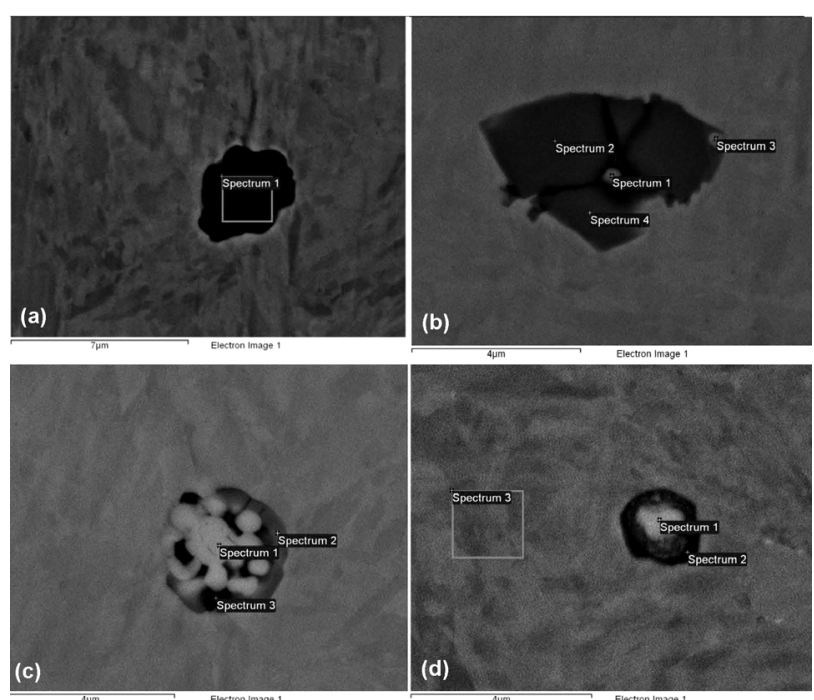

Figure 9: Typical oxide inclusions from samples a) PK942, b) PK942Ti, c) PK942 Zr, d) PK942TiZr addition, but with a large majority of the inclusions modified by both $\mathrm{Ti}$ and $\mathrm{Zr}$ (Figure 7).

\subsection{EDS}

Typical samples of oxide inclusions are shown in Figure 9a to 9d. The analysed non-metallic inclusions are oxides as they represent the bulk of the inclusions. The PK942 sample contains oxide non-metallic inclusions that are mostly manganese silicates, as shown in Figure 9a/Table 3. The de-oxidation with titanium results in the formation of titanium oxides as it has a higher affinity for oxygen than $\mathrm{Mn}$ and $\mathrm{Si}$ (Figure 9b/ Table 3). Due to the strong de-oxidation nature of $\mathrm{Zr}$, $\mathrm{ZrO}_{2}$ inclusions are formed first and then provide nucleation for many different phases, ${ }^{13,23,24}$ for example, the Zr-Ti-O inclusion in Figure 9d/Table 3. PK942TiZr has a $\mathrm{MnS}$ attached, $\mathrm{ZrO}_{2}$ provides the nucleation sites for $\mathrm{MnS}$ as they have small misfit in the lattice parameters. ${ }^{16,23}$ This is why zirconium additions are known to improve the impact toughness through sulphide modification. ${ }^{10}$

The SEM EDS results show that the complexity of the non-metallic inclusions is increased with $\mathrm{Ti}, \mathrm{Zr}$ and $\mathrm{Ti}+\mathrm{Zr}$ de-oxidation. The SEM micrograph in Figure 9c also shows that the larger zirconium oxides are mostly agglomerated smaller $\mathrm{ZrO}_{2}$ spheres with the attachment of other oxides.

\section{CONCLUSIONS}

No significant changes other than a decreased content of $\delta$-ferrite in the zirconium de-oxidised sample were observed in the microstructure when titanium or both titanium and zirconium were added. However, there was a significant impact on the non-metallic inclusions.

The addition of titanium did not have any significant effect on the size distribution and the number of non-metallic inclusions, but it did have a significant 


\section{KOLEŽNIK et al.: DE-OXIDATION OF PK942 STEEL WITH Ti AND Zr}

effect on the composition of the non-metallic inclusions, as a majority of the inclusions contained Ti.

The addition of zirconium had a great effect on the size distribution and the number of non-metallic inclusions. The inclusions were significantly smaller and the number was much higher $(300 \%$ compared to PK942), the result was a large reduction in the total non-metallic inclusion surface area (37\% reduction). Most of the inclusions contained $\mathrm{Zr}$. This means that the de-oxidation with zirconium is potentially beneficial for the production of clean steel.

The addition of both titanium and zirconium also resulted in smaller (over $60 \%$ of non-metallic inclusions are smaller than $1 \mu \mathrm{m})$ but more numerous non-metallic inclusions that had a reduced total non-metallic inclusion surface area $(28.5 \%)$ in comparison to the PK942 sample. The vast majority of inclusions contain both $\mathrm{Ti}$ and $\mathrm{Zr}$.

\section{REFERENCES}

${ }^{1}$ H. K. D. H. Bhadeshia, Design of ferritic creep-resistant steels, ISIJ Int. 41 (2001) 626-640

${ }^{2}$ B. Žužek, F. Vodopivec, B. Podgornik, M. Jenko, M. Godec, Calculation of accelerated stationary creep rate activation energy for a steel microstructure with a uniform distribution of carbide particles, Mater. Tehnol., 46 (2012) 661-664

${ }^{3}$ B. Žužek, F. Vodopivec, M. Jenko, B. Podgornik, Effect of creep strain on creep rate in the temperature range 550-640 ${ }^{\circ} \mathrm{C}$, Mater. Tehnol., 48 (2014) 545-548.

${ }^{4}$ F. Vodopivec, F. Kafexhiu, B. Žužek, B. Podgornik, Glide Stress by Stationary Creep of Tempered Martensite with Polyhedral Particles, Steel Res. Int., 88 (2017), 1600200, doi:10.1002/srin.201600200

${ }^{5}$ F. Vodopivec, F. Kafexhiu, B. Žužek, Effect of Ferrite Lattice Vacancies on Creep Rate of the Steel X20CrMoV121 in the Range 763-913 K, Steel Res. Int., 88 (2017), e201600315, doi:10.1002/srin. 201600315

${ }^{6}$ B. Žužek, F. Kafexhiu, B. Podgornik, F. Vodopivec, Effect of carbides size and distribution on creep rate, Metalurgija, 56 (2017), 323-325

${ }^{7}$ F. Abe, T. Kern, R. Viswanathan, $1^{\text {st }}$ ed., Creep-resistant steels, Woodhead Publishing Limited, Cambridge, 2008, 678

${ }^{8}$ C. Mapelli, Non-metallic inclusions and clean steel, Metall. Ital., 100 (2008), 43-52

${ }^{9}$ Y. Li, X.L. Wan, W.Y. Lu, A.A. Shirzadi, O. Isayev, O. Hress, K.M. $\mathrm{Wu}$, Effect of Zr-Ti combined deoxidation on the microstructure and mechanical properties of high-strength low-alloy steels, Mater. Sci. Eng. A., 659 (2016), 179-187, doi:10.1016/j.msea.2016.02.035

${ }^{10}$ H. Suito, A.V. Karasev, M. Hamada, R. Inoue, K. Nakajima, Influence of Oxide Particles and Residual Elements on Microstructure and Toughness in the Heat-Affected Zone of Low-Carbon Steel Deoxidized with $\mathrm{Ti}$ and $\mathrm{Zr}$, ISIJ Int., 51 (2011), 1151-1162, doi:10.2355/isijinternational.51.1151
${ }^{11}$ J. Janis, A. Karasev, K. Nakajima, P. Jönsson, Effect of Secondary Nitride Particles on Grain Growth in a Fe-20 mass\% Cr Alloy Deoxidised with $\mathrm{Ti}$ and $\mathrm{Zr}$, ISIJ Int., 53 (2013), 476-483, doi:10.2355/isijinternational.53.476

${ }^{12}$ L. Zhang, T. Kannengiesser, Austenite grain growth and microstructure control in simulated heat affected zones of microalloyed HSLA steel, Mater. Sci. Eng. A., 613 (2014), 326-335, doi:10.1016/j.msea. 2014.06.106

${ }^{13}$ T.N. Baker, Role of zirconium in microalloyed steels: a review, Mater. Sci. Technol., 31 (2015), 265-294, doi:10.1179/ 1743284714Y.0000000549

${ }^{14}$ C. Wang, Z. Wang, G. Wang, Effect of Hot Deformation and Controlled Cooling Process on Microstructures of $\mathrm{Ti}-\mathrm{Zr}$ Deoxidized Low Carbon Steel, ISIJ Int., 56 (2016), 1800-1807, doi:10.2355/isijinternational.ISIJINT-2016-106

${ }^{15}$ P. V. Bizyukov, S.R. Giese, Effects of Zr, Ti and Al Additions on Nonmetallic Inclusions and Impact Toughness of Cast Low-Alloy Steel, J. Mater. Eng. Perform., 26 (2017), 1878-1889, doi:10.1007/ s11665-017-2583-0

${ }^{16}$ Y. Du, K.M. Wu, L. Cheng, Y. Li, O. Isayev, O. Hress, Effect of $\mathrm{Zr}-\mathrm{Ti}$ deoxidisation on the hydrogen-induced cracking of X65 pipeline steels, Mater. Sci. Technol., 32 (2016), 728-735, doi:10.1080/02670836.2016.1157971

${ }^{17}$ ASTM International, ASTM E112-13 Standard Test Methods for Determining Average Grain Size, Subcommittee E04.08 on Grain Size, 2013, doi:10.1520/E0112

${ }^{18}$ H. Suito, H. Ohta, S. Morioka, Refinement of solidification microstructure and austenite grain by fine inclusion particles, ISIJ Int., 46 (2006), 840-846. doi:10.2355/isijinternational.46.840

${ }^{19}$ F. Tehovnik, F. Vodopivec, L. Kosec, M. Godec, Hot ductility of austenite stainless steel with a solidification structure, Mater. Tehnol., 40 (2006), 129-137

${ }^{20} \mathrm{H}$. Ohta, H. Suito, Dispersion Behavior of $\mathrm{MgO}, \mathrm{ZrO} 2, \mathrm{Al} 2 \mathrm{O} 3$, $\mathrm{CaO}-\mathrm{A} 12 \mathrm{O} 3$ and $\mathrm{MnO}-\mathrm{SiO} 2$ Deoxidation Particles during Solidification of $\mathrm{Fe}-10 \mathrm{mass} \% \mathrm{Ni}$ Alloy, ISIJ Int., 46 (2006), 22-28, doi:10.2355/isijinternational.46.22

${ }^{21}$ A. V Karasev, H. Suito, Quantitative evaluation of inclusion in deoxidation of $\mathrm{Fe}-10$ mass\% Ni alloy with $\mathrm{Si}, \mathrm{T}, \mathrm{Al}, \mathrm{Zr}$, and Ce, Metall. Mater. Trans. B Vol.30B, 30B (1999), 249-257, doi:10.1007/ s11663-999-0054-1

${ }^{22}$ A. V. Karasev, H. Suito, Nitride Precipitation on Particles in $\mathrm{Fe}-10 \mathrm{mass} \% \mathrm{Ni}$ Alloy Deoxidized with $\mathrm{Ti}, \mathrm{M}(\mathrm{M}=\mathrm{Mg}, \mathrm{Zr}$ and $\mathrm{Ce})$ and Ti/M, ISIJ Int., 49 (2009), 229-238, doi:10.2355/isijinternational.49.229

${ }^{23}$ H. Ohta, H. Suito, Precipitation and Dispersion Control of MnS by Deoxidation Products of $\mathrm{ZrO} 2, \mathrm{~A} 12 \mathrm{O} 3, \mathrm{MgO}$ and $\mathrm{MnO}-\mathrm{SiO} 2$ Particles in Fe - 10mass \% Ni Alloy, ISIJ Int., 46 (2006), 480-489

${ }^{24}$ Y. Min, X. Li, Z. Yu, C. Liu, M. Jiang, Characterization of the Acicular Ferrite in Al-Deoxidized Low-Carbon Steel Combined with $\mathrm{Zr}$ and $\mathrm{Mg}$ Additions, Steel Res. Int., 87 (2016), 1503-1510, doi:10.1002/srin.201500440 